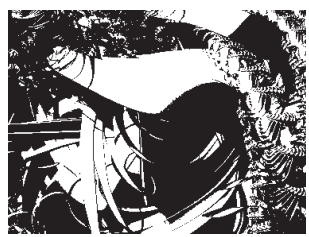

\title{
NEKI ASPEKTI BRIGE ODRASLIH ZA MLAĐE GENERACIJE: SPOLNE I DOBNE RAZLIKE
}

Ivana TUCAK JUNAKOVIĆ

Sveučilište u Zadru, Zadar

UDK: 159.922 .6

Izvorni znanstveni rad

Primljeno: 12. 10. 2009.

Napomena: Prikazani rezultati dio su projekta Iskustva nepravde psihološka dobrobit tijekom nekih životnih tranzicija (269.

Eriksonov koncept generativnosti odnosi se na brigu za mlađe generacije i za vlastite trajne doprinose drušłvu, koja je glavno obiliežje srednje dobi. Konstrukt generativnosti je nakon Eriksona doživio brojna proširenja, a njegovu najširu razradbu predstavlja McAdamsov i de St. Aubinov model generativnosti (1992.). U raniijim provjerama modela ispitivani su odnosi između manjega broja njegovih komponenti. Stoga je provedeno istraživanje kojemu je cili bio provjeriti odnose između pet, od ukupno sedam, komponenti modela (generativne želje, brige, predanosti, vjere $u$ vrstu i generativnoga djelovanja) te spolne i dobne razlike u tim komponentama. U istraživanju je sudjelovalo 300 osoba od 25 do 75 godina. Komponente generativnosti ispitane su skalama, njihovim adaptiranim i kulturno prilagođenim verzijama ili novokonstruiranim skalama. U skladu s očekivanjima, analize su pokazale da su gotovo sve ispitane komponente generativnosti značajno i pozitivno povezane. Dobiveni rezultati također sugeriraju da generativnost nije razvojno obilježje samo srednje nego čitave odrasle dobi. Nadalje, nisu utvrđene značajne spolne razlike u većini ispitanih komponenti generativnosti. Jedino su orijentacija zajedništvu (kao dio generativne želie) i generativno djelovanje bili značajno izraženiiji u žena. Dobiveni rezultati interpretirani su u skladu s teorijskim pristupima generativnosti, primarno Eriksonovim te McAdamsovim i de St. Aubinovim, kao i u kontekstu teorija razvoja u odrasloj dobi.

Ključne riječi: generativnost, McAdamsov i de St. Aubinov model, odrasla dob 
"Briga za stvaranje i vođenje sljedeće generacije" (Erikson, 1984., 240) jedna je od najstarijih definicija generativnosti. Konstrukt generativnosti u psihologiju je uveo Erikson 1950-ih godina u svojoj psihosocijalnoj teoriji razvoja. Erikson je smatrao da je generativnost glavno obilježje sedmoga stadija razvoja u njegovoj teoriji, tj. srednje odrasle dobi. Mnogi su autori proširivali Eriksonove ideje o generativnosti (Bradley i Marcia, 1998.; McAdams i sur., 1998.; Peterson i Stewart, 1996.; Stewart i Vandewater, 1998. i dr.). Iz nastalih objašnjenja ovoga konstrukta može se zaključiti da je generativnost širok pojam, koji uključuje stvaranje i brigu o djeci, stvarima i idejama koji će nadživjeti pojedinca i koji pridonose dobrobiti i održavanju društvenoga kontinuiteta.

Najšira elaboracija konstrukta generativnosti do danas je McAdamsov i de St. Aubinov model (McAdams i de St. Aubin, 1992.). Ovaj model prikazuje generativnost kao složeni psihosocijalni konstrukt koji uključuje sedam povezanih komponenti: (1) kulturni zahtjevi za generationosti ("cultural demand") usmjereni na odrasle osobe s ciljem da one preuzmu odgovornost za dobrobit mlađih generacija i pojedinčeva (2) želja ("inner desire") za generativnosti osnovni su motivacijski izvori generativnosti. Pritom želja uključuje dvije osnovne tendencije ljudskoga ponašanja, djelovanje ("agency") i zajedništvo ("communion"). Djelovanje se odnosi na potrebu da se ostavi za sobom zamjetan trag, a zajedništvo na potrebu da se brine, pomaže i poučava druge, posebno pripadnike mlađih generacija. Kulturni zahtjevi i želja udružuju se kako bi potaknuli (3) generationu brigu ("concern"), opću svjesnu usmjerenost na dobrobit sljedeće generacije. Briga vodi (4) predanosti ("commitment") odlukama i ciljevima usmjerenima (5) generativnom djelovanju ("generative action"). Generativno djelovanje uključuje: stvaranje pozitivnih produkata (osobe, stvari, ideje itd.), čuvanje ili oplemenjivanje onoga što je već stvoreno i prenošenje onoga što je stvoreno i sačuvano sljedećoj generaciji (McAdams i de St. Aubin, 1992.; McAdams i sur., 1993.). Generativna predanost trebala bi biti ojačana tzv. (6) vjerom $u$ vrijednost ljudskoga djelovanja ili vjerom $u$ vrstu ("belief in the species"), kako je naziva Erikson (1984.). To je temeljno uvjerenje da je život u osnovi dobar i vrijedan življenja, osobito kada se predviđa $\mathrm{u}$ budućnosti. Komponenta vjere u vrstu uključuje dvije relativno nezavisne potkomponente, povjerenje u ljude i nadu u bolju budućnost (McAdams i sur., 1998.). Konačno, osobno značenje vezama između prethodnih komponenti pojedinac daje stvaranjem (7) generativne priče ("narration"), priče koju odrasla osoba stvara o brizi za sljedeću generaciju, stvarajući tako mit o vlastitim generativnim naporima. 
DRUŠ. ISTRAŽ. ZAGREB GOD. 20 (2011), BR. 3 (113)

STR. 671-692

TUCAK JUNAKOVIĆ, I.: NEKI ASPEKTI BRIGE...
McAdams i de St. Aubin (1992.) pokušali su operacionalizirati neke od komponenti svoga modela, i to primjenom metoda mjerenja različitih komponenti. Tako su generativnu brigu, najčešće ispitivanu središnju komponentu modela, ispitivali skalom samoprocjene, poznatom Loyola skalom generativnosti (LGS, McAdams i de St. Aubin, 1992.). Predanost generativnim ciljevima ispitivali su kodiranjem generativnih sadržaja u opisima svakodnevnih osobnih težnji (McAdams i sur., 1993.), generativno djelovanje ček-listom generativnoga ponašanja (GBC, McAdams i de St. Aubin, 1992.), a generativnu priču kodiranjem generativnih tema u ključnim autobiografskim sjećanjima odraslih osoba (McAdams i de St. Aubin, 1992.; McAdams i sur., 1993.). Kako druga komponenta modela - generativna želja - uključuje orijentaciju djelovanju i zajedništvu, bilo je pokušaja ispitivanja ove komponente projektivnim mjerama motiva usmjerenih na djelovanje i zajedništvo (McAdams i sur., 1986.; Peterson i Stewart, 1993.). Kasnije su Peterson i Stewart (1996.) jasnije operacionalizirali generativnu želju projektivnom mjerom generativne motivacije, tj. željom da se pridonese dobrobiti društva.

U kasnijem opisu istraživanja o kojem ovaj rad referira bit će izložen drugačiji metodološki pristup ispitivanju komponente generativne želje. Naime, budući da se ovu komponentu namjeravalo zahvatiti u terminima eksplicitnih svjesnih ciljeva djelovanja i zajedništva, a ne u terminima implicitnih nesvjesnih motiva, u istraživanju koje će biti opisano u nastavku generativna želja operacionalizirana je upitnikom koji ispituje ciljeve usmjerene djelovanju i zajedništvu.

Uz komponentu kulturnih zahtjeva za generativnošću, koju je teško operacionalizirati, najmanje je interesa pobudila komponenta vjere $u$ vrstu. Dosad nije bilo pokušaja izravne operacionalizacije ove komponente, nego je neizravno ispitivana skalama koje mjere slične konstrukte (npr. vjera u ljude, povjerenje) (Van de Water i McAdams, 1989.).

Dijelom i zbog problema operacionalizacije nekih njegovih komponenti, još nisu ispitani odnosi između svih komponenti McAdamsova i de St. Aubinova modela. Rezultati ranijih istraživanja pokazali su postojanje umjereno visokih i značajnih korelacija između generativne brige, predanosti, djelovanja i priče (Hart i sur., 2001.; McAdams i de St. Aubin, 1992.; McAdams i sur., 1993.).

Za razliku od ranijih istraživanja usmjerenih na validaciju instrumenata za ispitivanje generativnosti, novija su istraživanja sve više usmjerena prema ispitivanju njezinih korelata. Među najistraživanijima su demografske karakteristike i varijable dobrobiti. Međutim, rezultati istraživanja odnosa generativnosti i ovih korelata nisu sasvim podudarni. Također, $\mathrm{u}$ ranijim istraživanjima spolnih i dobnih razlika u generativ- 
DRUŠ. ISTRAŽ. ZAGREB GOD. 20 (2011) BR. $3(113)$

STR. 671-692

TUCAK JUNAKOVIĆ, I. NEKI ASPEKTI BRIGE... nosti nije zahvaćen veći broj komponenti McAdamsova i de St. Aubinova modela. U njima su uglavnom ispitivane komponente generativne brige i djelovanja.

U pogledu dobnih razlika u generativnosti, neka od ranijih istraživanja pokazala su da je generativnost, u skladu s razvojnim očekivanjima, najrazvijenija $u$ srednjoj odrasloj dobi (Keyes i Ryff, 1998.; McAdams i sur., 1993.; Peterson i Klohnen, 1995. i dr.), zbog razvojne spremnosti pojedinca i društvenih zahtjeva za generativnim djelovanjem. Suprotno tome, druga istraživanja nisu potvrdila značajnu povezanost nekih komponenti generativnosti s dobi (Hart i sur., 2001.; McAdams i de St. Aubin, 1992.).

U pogledu spolnih razlika, rezultati ranijih istraživanja također nisu jednoznačni. U većini onih istraživanja u kojima je generativnost zahvaćena kao jednodimenzionalni konstrukt nisu utvrđene spolne razlike $\mathrm{u}$ generativnosti (npr. Domino i Hannah, 1989.; Peterson i Duncan, 1999.). Međutim, čini se da se tretiranjem generativnosti kao homogenoga konstrukta maskiraju moguće spolne razlike u pojedinim dijelovima ovoga konstrukta. Tako su među onim studijama koje su ispitivale spolne razlike $\mathrm{u}$ pojedinim komponentama generativnosti iz McAdamsova i de St. Aubinova modela neke pokazale da su generativna briga i djelovanje izraženiji u žena (Hart i sur., 2001.; McAdams i de St. Aubin, 1992.). Druge studije ove nalaze nisu potvrdile (McAdams i sur., 1993.; Tucak, 2005.) ili su pokazale da se muškarci i žene ne razlikuju značajno ni u drugim komponentama generativnosti, poput generativne predanosti i priče (Hart i sur., 2001.; McAdams i sur., 1993.). Ni nalazi o relativnoj važnosti aspekta djelovanja (agency) i aspekta zajedništva (communion) za generativnost žena i muškaraca nisu jednoznačni. Tako neki potvrđuju pretpostavke, u skladu s razlikama u socijalizaciji rodnih uloga, da je tendencija pomaganja drugima i prisnoga povezivanja s njima (zajedništvo) izraženija u generativnim preokupacijama žena, a tendencija da se bude nezavisan, dominantan i da se ostvari utjecaj na druge (djelovanje) u generativnosti muškaraca, dok rezultati drugih istraživanja te pretpostavke uopće ne potvrđuju ili ih potvrđuju samo djelomično (Ackerman i sur., 2000.; Bradley i Marcia, 1998.; Morfei i sur., 2004.).

Premda je u ovome radu interes usmjeren na spolne i dobne razlike $u$ generativnosti, treba naglasiti da je $u$ dosadašnjim istraživanjima zahvaćen velik broj njezinih potencijalnih korelata. Ispitivani su odnosi generativnosti s roditeljstvom, psihološkom dobrobiti, društvenim i političkim angažmanom, osobinama ličnosti itd. U ovim je istraživanjima, primjerice, utvrđeno da je očinstvo, ali ne i majčinstvo, povezano s generativnom brigom (McAdams i de St. Aubin, 1992.), da je generativnost povezana s pozitivnim oblicima uključenosti rodi- 
DRUŠ. ISTRAŽ. ZAGREB GOD. 20 (2011), BR. 3 (113)

STR. $671-692$

TUCAK JUNAKOVIĆ, I.: NEKI ASPEKTI BRIGE...

(1) SLIKA 1

McAdamsov i de St. Aubinor model generativnosti (1992.) telja u odgoj djece i s autoritativnim stilom roditeljstva (Peterson i sur., 1997.) te s društvenim i političkim angažmanom koje unaprjeđuje društvo (Peterson i Duncan, 1999.; Peterson i Klohnen, 1995.; Peterson i Stewart, 1996.). Nadalje, pokazalo se da generativne osobe imaju prosocijalne osobine ličnosti, osobine dobroga vođe, da su ekstravertirane, otvorene novim iskustvima i emocionalno stabilne (Bradley i Marcia, 1998.; de St. Aubin i McAdams, 1995.; Peterson i Klohnen, 1995.) te da je generativnost pozitivno povezana s raznim varijablama dobrobiti, kao što su životno zadovoljstvo, samopoštovanje, sreća, osobni rast, doživljaj svrhe života i druge (Ackerman i sur., 2000.; de St. Aubin i McAdams, 1995.; Keyes i Ryff, 1998.; McAdams i sur., 1993.; Shin An i Cooney, 2006.).

Polazeći od ranije navedenoga, provedeno je istraživanje kojemu je cilj bio ispitati odnose među pojedinim komponentama generativnosti i pridonijeti postojećim spoznajama o relacijama generativnosti s demografskim karakteristikama, kao što su spol i dob. Riječ je o pokušaju djelomične provjere McAdamsova i de St. Aubinova modela - izvorno nastalog $\mathrm{u}$ sjevernoameričkom okruženju - u hrvatskom kulturnom okruženju. Pritom smo se usmjerili na pet komponenti generativnosti iz McAdamsova i de St. Aubinova modela, od kojih generativna želja i vjera u vrstu imaju dvije potkomponente. Komponente modela zahvaćene ovim istraživanjem prikazane su na Slici 1. Kao što se može primijetiti, istraživanjem nije zahvaćeno svih sedam komponenti. Jedan od razloga tomu jest što je komponentu kulturnih zahtjeva za generativnosti teško direktno operacionalizirati, dok bi komponenta generativne priče zahtijevala drugačiju operacionalizaciju u odnosu na skale samoprocjene, vjerojatno primjenu kvalitativne metode, što nadilazi ambicije provedenoga istraživanja.

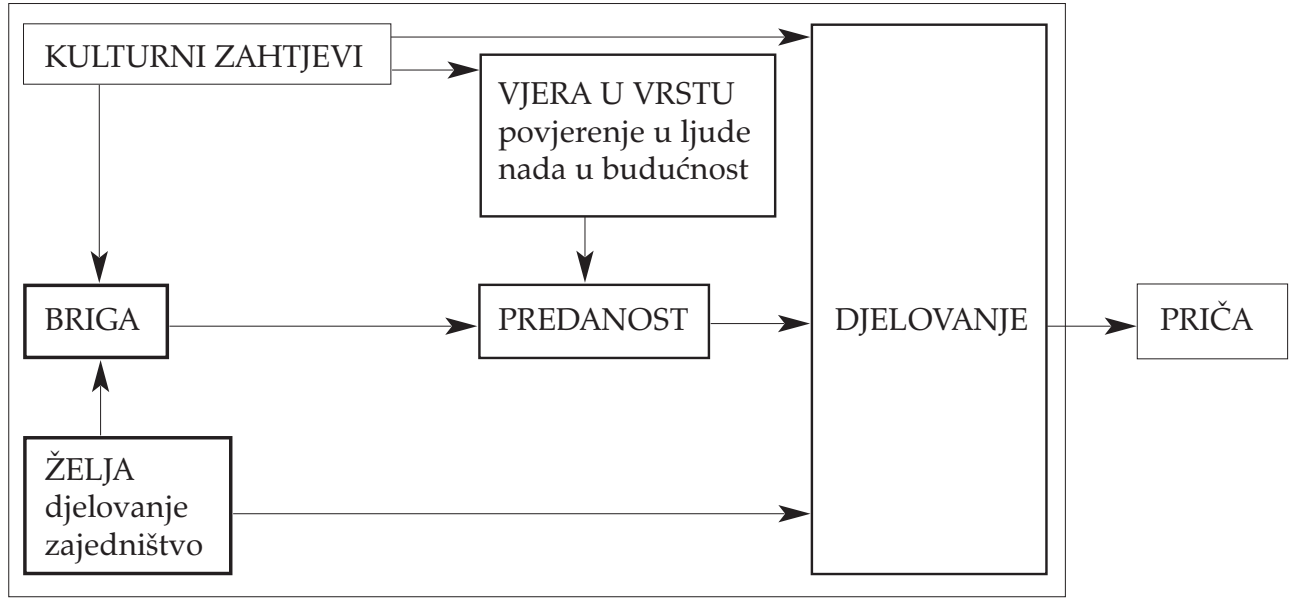

Napomena: Na slici je prikazana jednostavnija verzija modela bez povratnih veza među komponentama; komponente koje su ispitane $\mathrm{u}$ ovom istraživanju prikazane su debljim pravokutnicima 
DRUŠ. ISTRAŽ. ZAGREB GOD. 20 (2011), BR. 3 (113)

STR. 671-692

TUCAK JUNAKOVIĆ, I. NEKI ASPEKTI BRIGE...
Problemi na koje se istraživanjem pokušalo odgovoriti jesu:

1. Ispitati korelacije između pet komponenti generativnosti iz McAdamsova i de St. Aubinova modela (generativna želja s potkomponentama djelovanja i zajedništva, generativna briga, vjera $\mathrm{u}$ vrstu s potkomponentama povjerenja $\mathrm{u}$ ljude i nade $\mathrm{u}$ budućnost, predanost generativnim ciljevima i generativno djelovanje).

U skladu s postavkama modela, pretpostavljeno je da će ispitane komponente generativnosti biti značajno i umjereno visoko povezane.

2. Ispitati postoje li dobne $\mathrm{i} / \mathrm{ili}$ spolne razlike $\mathrm{u}$ izraženosti pet komponenti generativnosti iz McAdamsova i de St. Aubinova modela.

U skladu s razvojnim očekivanjima i rezultatima nekih ranijih istraživanja, pretpostavljeno je da će pojedine komponente generativnosti biti najizraženije $u$ srednjoj odrasloj dobi, uz iznimku komponente generativne želje, posebno njezina aspekta djelovanja. Naime, neki su raniji nalazi pokazali da je želja za generativnosti najizraženija u ranoj odrasloj dobi (Stewart i Vandewater, 1998.). Nadalje je pretpostavljeno da spolne razlike u pojedinim komponentama generativnosti neće biti značajne, uz iznimku očekivanih značajnih spolnih razlika u potkomponentama djelovanja i zajedništva unutar generativne želje. U skladu s rezultatima ranijih istraživanja, pretpostavljeno je da bi djelovanje moglo biti izraženije u muškaraca, a zajedništvo u žena.

Mogući interakcijski utjecaj spola i dobi na generativnost također treba ispitati jer su neka istraživanja našla spolne razlike (u smjeru izraženije generativnosti u žena) samo u mlađim, ali ne i u starijim skupinama odrasle dobi (McAdams i de St. Aubin, 1992.).

\section{METODA}

\section{Sudionici}

U istraživanju je sudjelovalo 300 osoba od 25 do 75 godina $(\mathrm{M}=50,5, \mathrm{SD}=14,6)$ iz raznih dijelova Hrvatske. Polovicu uzorka činile su žene. Kako se nastojao formirati uzorak odraslih kontinuiran s obzirom na dob, različite dobne podskupine $u$ njemu bile su otprilike podjednako zastupljene (tj. isti broj sudionika u podskupinama od 25 do 35, od 35 do 45 godina itd.). Premda je uzorak prigodan, nastojalo se da u svakoj dobnoj podskupini budu zahvaćene osobe heterogenih sociode- 
DRUŠ. ISTRAŽ. ZAGREB GOD. 20 (2011), BR. 3 (113)

STR. $671-692$

TUCAK JUNAKOVIĆ, I.: NEKI ASPEKTI BRIGE...

\section{Instrumenti}

mografskih karakteristika. Među sudionicima istraživanja bilo je $55 \%$ zaposlenih, $16 \%$ nezaposlenih i $29 \%$ umirovljenih osoba. Većina sudionika završila je srednjoškolsko obrazovanje (raspon godina školovanja: $8-23$ godine, $\mathrm{M}=12,5, \mathrm{SD}=2,8$ ). Većina sudionika bila je u braku (77\%) te je imala djecu (83\%). Samci su činili $10 \%$ uzorka, udovci $6 \%, 4 \%$ oni koji su živjeli u nevjenčanoj zajednici, a 3\% uzorka činile su rastavljene osobe.

U istraživanju je primijenjen upitnik koji je sadržavao u nastavku opisane instrumente.

1. Skraćena verzija upitnika važnosti životnih ciljeva (Pöhlmann i Brunstein, 1997./ Tucak Junaković, 2008.) predstavlja adaptaciju Upitnika životnih ciljeva (GOALS, Pöhlmann i Brunstein, 1997.). Upotrijebljena je kao približna operacionalizacija želje za generativnosti, kao komponente McAdamsova i de St. Aubinova modela. Opravdanje za to jest činjenica da su GOALS-om Pöhlmann i Brunstein pokušali zahvatiti dvije osnovne ljudske tendencije, djelovanje i zajedništvo. McAdams $\mathrm{i}$ de St. Aubin iste te tendencije smatraju sastavnim dijelovima generativne želje.

Skraćena verzija Upitnika važnosti životnih ciljeva uključuje četiri podskale sa četiri čestice. Podskale ispituju četiri domene životnih ciljeva: ciljeve intimnosti ("imati blisku vezu") i altruizma ("pomagati ljudima kojima je potrebno"), koji zahvaćaju sudjelujuću tendenciju ili zajedništvo, te ciljeve moći ("imati mogućnost utjecaja") i dostignuća ("kontinuirano unaprjeđivati obrazovanje"), koji se odnose na pokretačku tendenciju ili djelovanje. Ispitanici procjenjuju koliko im je važno postići svaki od 16 ciljeva iz četiri domene, i to na skali Likertova tipa od pet stupnjeva: od 1 - uopće mi nije važno, do 5 - vrlo mi je važno.

Pokazalo se da skraćena verzija Upitnika važnosti životnih ciljeva ima dvofaktorsku strukturu. Jedan faktor odnosi se na ciljeve djelovanja, a drugi na ciljeve zajedništva. Stoga $\mathrm{su}$, kao i zbog ranije navedenih razloga, u ovome radu razmatrane samo dimenzije djelovanja i zajedništva, koje proizlaze iz faktorske strukture upitnika. Ukupni rezultati izračunani su za skalu ciljeva djelovanja, kao prosjek rezultata na česticama podskala dostignuća i moći, te za skalu ciljeva zajedništva, na osnovi prosjeka rezultata na česticama podskala intimnosti i altruizma. Teoretski rasponi rezultata na njima kreću se između 1 i 5.

Koeficijent pouzdanosti Cronbach-alpha za skalu ciljeva usmjerenih djelovanju u uzorku ovoga istraživanja iznosio je 0,83 , a za skalu ciljeva usmjerenih zajedništvu 0,85 . 
DRUŠ. ISTRAŽ. ZAGREB GOD. 20 (2011) BR. $3(113)$

STR. 671-692

TUCAK JUNAKOVIĆ, I. NEKI ASPEKTI BRIGE...
2. Skraćena verzija Loyola skale generativnosti (LGS, McAdams i de St. Aubin, 1992./ Lacković-Grgin i sur., 2002.) upotrijebljena je za ispitivanje generativne brige, središnje komponente McAdamsova i de St. Aubinova modela. LGS, najčešće rabljena skala u istraživanjima generativnosti, u originalu sadrži 20 čestica, koje pokrivaju razne generativne sadržaje: prenošenje znanja i vještina sljedećoj generaciji, društvene doprinose, stvaranje trajne ostavštine, brigu i preuzimanje odgovornosti za druge itd. (npr. "Osjećam da će moji doprinosi postojati i nakon moje smrti").

Budući da su u ponavljanim provjerama psihometrijskih svojstava LGS na različitim uzorcima hrvatskih ispitanika (npr. Lacković-Grgin i sur., 2002.; Penezić i sur., 2008.) nezadovoljavajuća faktorska zasićenja i nisku korelaciju s ukupnim rezultatom dosljedno pokazivale tri čestice, odlučeno je da se one izbace iz verzije Loyola skale, upotrijebljene $\mathrm{u}$ ovome istraživanju. To su čestice koje se odnose na volontiranje u dobrotvornim aktivnostima, brigu društva za beskućnike i posvajanje djece. Tako skraćena verzija Loyola skale sadrži 17 čestica, od kojih su 4 negativno formulirane. Ispitanici odgovaraju na skali Likertova tipa od pet stupnjeva. Ukupan rezultat formira se kao prosječna vrijednost procjena na pojedinim česticama, tako da se teoretski raspon rezultata na skali kreće od 1 do 5. Pritom viši rezultat upućuje na veću usmjerenost pojedinca na dobrobit sljedeće generacije. Koeficijent pouzdanosti Cronbach-alpha ove skraćene verzije LGS u uzorku ovoga istraživanja iznosio je 0,87 .

3. Skala generatione predanosti (Tucak Junaković, 2009.) namijenjena je ispitivanju predanosti generativnim ciljevima, komponenti McAdamsova i de St. Aubinova modela. Kako je ona ranije ispitivana kodiranjem generativnih sadržaja u ispitanikovim slobodnim opisima svakodnevnih osobnih težnji, ova skala samoprocjene predstavlja metodološki drugačiji i jednostavniji pokušaj ispitivanja generativne predanosti.

Skala sadrži 19 čestica, tj. generativnih ciljeva (npr. "stvaranje vrijedne ostavštine budućim generacijama", "nastojanje da se ostavi vlastiti trag u svijetu"). Ispitanici na skali Likertova tipa od pet stupnjeva, od 1 (uopće nisam predan) do 5 (potpuno sam predan), procjenjuju koliko su svakodnevno osobno predani nastojanju da postignu svaki od navedenih ciljeva. Ukupan rezultat na skali formira se kao prosječna vrijednost procjena na pojedinim česticama, tako da se teoretski raspon rezultata kreće od 1 do 5 . Viši rezultat upućuje na veću generativnu predanost.

U ranijim primjenama u uzorcima odraslih ispitanika skala je pokazala visoku pouzdanost tipa unutarnje konzistencije i značajne korelacije s drugim komponentama generativnosti. U uzorku ovoga istraživanja dobiven je koeficijent Cronbach-alpha skale od čak 0,91 . 
DRUŠ. ISTRAŽ. ZAGREB GOD. 20 (2011), BR. 3 (113),

STR. 671-692

TUCAK JUNAKOVIĆ, I.: NEKI ASPEKTI BRIGE...
4. Skala povjerenja u ljude jest podskala Skale cinizma i povjerenja (CIP, Ćubela Adorić i Tucak, 2006.), koja je nastala adaptacijom Skale filozofija o ljudskoj prirodi (PHN, Wrightsman, 1992.). Podskala povjerenja u ljude ispituje uvjerenje da je većina ljudi u osnovi dobra, tj. da su ljudi moralni, odgovorni, altruistični, da im se može vjerovati i da su iskreno zainteresirani za druge (npr. "Prosječna osoba iskreno je zainteresirana za probleme drugih ljudi"). Za potrebe ovoga istraživanja skala povjerenja uzeta je u svrhu operacionalizacije jednog aspekta komponente vjere $\mathrm{u}$ vrstu, aspekta koji se odnosi na povjerenje u ljude.

Ispitanik izražava stupanj svojega (ne)slaganja sa svakom tvrdnjom na skali od šest stupnjeva, od -3 (uopće se ne slažem) do +3 (potpuno se slažem). Ukupan rezultat na skali određuje se kao prosjek procjena na pojedinim česticama. Stoga se mogući raspon rezultata kreće od -3 do +3 .

$\mathrm{U}$ ranijim provjerama skale $\mathrm{u}$ studentskim uzorcima i u hrvatskim i slovenskim uzorcima odraslih pokazalo se da skala ima zadovoljavajuću unutarnju konzistenciju i da korelira s nekim teorijski relevantnim konstruktima, kao što su vjerovanje u pravedan svijet, osjećaj koherentnosti, generativna briga itd. (Ćubela Adorić i Tucak, 2006.).

U ovome istraživanju Skala povjerenja u ljude također je pokazala zadovoljavajuću unutarnju pouzdanost (Cronbach-alpha iznosio je 0,81).

5. Skala nade u budućnost (Tucak Junaković, 2009.) konstruirana je radi ispitivanja drugog aspekta komponente vjere u vrstu, a to je nada u bolju budućnost. Sastoji se od 8 tvrdnji. Ispitanik izražava stupanj svojega (ne)slaganja sa svakom od njih na skali Likertova tipa od pet stupnjeva, od 1 (uopće se ne slažem) do 5 (potpuno se slažem). Tvrdnje zahvaćaju vjerovanje da je život u osnovi dobar i vrijedan življenja, optimizam u odnosu na budućnost, nadu da će život za buduće generacije biti bolji i sl. (npr. "Nadam se poboljšanju života u budućim generacijama."). Ukupan rezultat na skali jest prosječna vrijednost procjena na pojedinim česticama skale. Teoretski raspon rezultata kreće se između 1 i 5 . Pritom viši rezultat upućuje na izraženiju nadu u bolju budućnost.

U ranijoj provjeri metrijskih obilježja skale u manjem uzorku odraslih osoba potvrđena je njezina jednofaktorska struktura i visoka pouzdanost tipa unutarnje konzistencije. U uzorku ovoga istraživanja utvrđen je koeficijent Cronbach-alpha od 0,88 .

6. Skala generationoga djelovanja (Tucak, 2006.) namijenjena je procjeni komponente generativnoga djelovanja. Uključuje 25 aktivnosti usmjerenih dobrobiti mlađih generacija i društva u cjelini, kao i aktivnosti koje su izraz kreativnih i produktivnih nastojanja pojedinca (npr. "poučiti nekoga određe- 
DRUŠ. ISTRAŽ. ZAGREB GOD. 20 (2011)

BR. 3 (113)

STR. 671-692

TUCAK JUNAKOVIĆ, I. NEKI ASPEKTI BRIGE... noj vještini"). Ispitanik za svaku generativnu aktivnost navedenu u skali procjenjuje učestalost njezina izvođenja u zadnja dva mjeseca na skali od 5 stupnjeva: od 1 (vrlo rijetko ili nikako) do 5 (vrlo često ili gotovo uvijek). Ukupan rezultat na skali određuje se kao prosječna vrijednost procjena na pojedinim česticama, tako da je teoretski raspon rezultata od 1 do 5. Pritom viši rezultat upućuje na veću razinu generativnoga djelovanja. Način na koji je ova skala konstruirana i njezine psihometrijske karakteristike detaljnije su opisane u Tucak Junaković (2009.).

$\mathrm{U}$ ovom istraživanju skala je pokazala relativno visoku unutarnju pouzdanost (Cronbach-alpha iznosio je 0,88 ).

\section{Postupak ispitivanja}

Provedeno je istraživanje $\mathrm{u}$ raznim dijelovima Hrvatske, $\mathrm{u}$ ključujući Dalmaciju, šire područje Zagreba, Slavoniju, Istru, Primorsko-goransku županiju i sjevernu Hrvatsku. Uvježbani ispitivači obilazili su domove ili radna mjesta potencijalnih sudionika. Svaki je ispitivač imao zadatak da regrutira određen broj sudionika muškoga, odnosno ženskoga, spola u pojedinim dobnim podskupinama. Sudionici istraživanja upitnik bi popunili u svoje slobodno vrijeme $u$ roku od tjedan dana pošto bi im ispitivači uručili upitnik.

\section{REZULTATI}

\section{Osnovni deskriptivni podaci upotrijebljenih} instrumenata $i$ korelacije ispitivanih varijabli

Prije prikaza rezultata statističkih analiza koje će omogućiti da se odgovori na istraživačke probleme treba se osvrnuti na deskriptivne podatke upotrijebljenih skala, prikazane u Tablici 1.

\begin{tabular}{lrrrrr}
\hline Skala & $\begin{array}{r}\text { Aritmetička } \\
\text { sredina }\end{array}$ & $\begin{array}{r}\text { Najmanji } \\
\text { rezultat }\end{array}$ & $\begin{array}{r}\text { Najveći } \\
\text { rezultat }\end{array}$ & $\begin{array}{r}\text { Standardna } \\
\text { devijacija }\end{array}$ & $\begin{array}{r}\text { Cronbach- } \\
\text {-alpha }\end{array}$ \\
\hline Podskala ciljeva djelovanja & 3,59 & 1,25 & 5,00 & 0,68 & 0,83 \\
Podskala ciljeva zajedništva & 4,32 & 2,12 & 5,00 & 0,52 & 0,85 \\
Loyola skala generativnosti & 3,57 & 1,53 & 5,00 & 0,60 & 0,87 \\
Skala generativne predanosti & 3,82 & 1,79 & 4,95 & 0,58 & 0,91 \\
Skala povjerenja u ljude & 0,64 & $-3,00$ & 2,80 & 0,99 & 0,81 \\
Skala nade u budućnost & 4,03 & 1,50 & 5,00 & 0,69 & 0,88 \\
Skala generativnoga djelovanja & 2,84 & 1,16 & 4,48 & 0,60 & 0,88 \\
\hline
\end{tabular}

i TABLICA 1

Osnovni deskriptivni podaci instrumenata koji ispituju komponente generativnosti u ukupnom uzorku odraslih $(\mathrm{N}=300)$
Rasponi i standardne devijacije rezultata na svim skalama namijenjenima ispitivanju komponenti generativnosti $\mathrm{u}-$ pućuju na njihovu zadovoljavajuću osjetljivost. Međutim, distribucije rezultata na svim skalama, osim na Skali generativnoga djelovanja, donekle su pomaknute prema višim vrijed- 
DRUŠ. ISTRAŽ. ZAGREB GOD. 20 (2011), BR. $3(113)$

STR. $671-692$

TUCAK JUNAKOVIĆ, I.: NEKI ASPEKTI BRIGE...

(1) TABLICA 2

Korelacije ispitivanih varijabli u ukupnom uzorku ispitanika odrasle dobi $(\mathrm{N}=300)$ nostima. Dakle, ciljevi djelovanja i zajedništva (kao procjena dvaju aspekata generativne želje) bili su sudionicima ovoga istraživanja uglavnom važni. Nadalje, ispitanici su se uglavnom slagali s tvrdnjama koje upućuju na generativnu brigu te su procjenjivali da su uglavnom predani generativnim ciljevima. Također su u prosjeku izrazili blago slaganje i s tvrdnjama Skale povjerenja u ljude koja ima nešto drugačiji format odgovaranja na tvrdnje $\mathrm{u}$ odnosu na ostale skale $\mathrm{u}$ ovom istraživanju. Na skali mogućega raspona rezultata od -3 do +3 prosječna vrijednost iznosila je $+0,64$, odražavajući u prosje$\mathrm{ku}$ blago slaganje sudionika ovoga istraživanja s uvjerenjem da su ljudi moralni, altruistični, da im se može vjerovati i da su iskreno zainteresirani za druge. U Tablici 1 ističe se visoka prosječna vrijednost rezultata na Skali nade u budućnost, što bi moglo odražavati težnju odraslih osoba sudionika ovoga istraživanja da sačuvaju fundamentalnu pozitivnu sliku o životu i svijetu kakav predviđaju u budućnosti. S druge strane, ispitanici su izvijestili o blago ispodprosječnoj ("rijetko" do "ponekad") frekvenciji izvođenja generativnih ponašanja, ispodprosječnoj u odnosu na središnju procjenu na skali koja iznosi 3.

Najviše vrijednosti prosječnih rezultata zabilježene su na skalama važnosti životnih ciljeva usmjerenih zajedništvu, iako su i životne ciljeve usmjerene djelovanju, sudionici također procjenjivali natprosječno važnima. Analiza varijance za ponovljena mjerenja pokazala je da je razlika u procjeni važnosti ciljeva djelovanja i zajedništva statistički značajna $(F(1,299)=339,08$, $\mathrm{p}<0,001)$. Pritom su sudionici značajno važnijima procjenjivali ciljeve zajedništva $(\mathrm{M}=4,32)$ u odnosu na ciljeve djelovanja $(\mathrm{M}=3,59)$.

Koeficijenti Cronbach-alpha pokazuju relativno visoku pouzdanost tipa unutarnje konzistencije pojedinih skala.

\begin{tabular}{|c|c|c|c|c|c|c|c|}
\hline Varijabla & 1 & 2 & 3 & 4 & 5 & 6 & 7 \\
\hline \multicolumn{8}{|l|}{ 1. Dob } \\
\hline 2. Djelovanje & $-0,23 * *$ & & & & & & \\
\hline 3. Zajedništvo & $-0,07$ & $0,37^{* *}$ & & & & & \\
\hline 4. Generativna briga & 0,06 & $0,35^{* *}$ & $0,48^{* *}$ & & & & \\
\hline 5. Generativna predanost & 0,06 & $0,37^{* *}$ & $0,44^{* *}$ & $0,71^{* *}$ & & & \\
\hline 6. Povjerenje u ljude & $0,28^{* *}$ & 0,02 & $0,14^{*}$ & $0,21^{* *}$ & $0,29 * *$ & & \\
\hline 7. Nada u budućnost & $-0,04$ & $0,29^{* *}$ & $0,39^{* *}$ & $0,27^{* *}$ & $0,29 * *$ & $0,20^{* *}$ & \\
\hline 8. Generativno djelovanje & $-0,03$ & $0,25^{* *}$ & $0,32^{* *}$ & $0,58^{* *}$ & $0,64^{* *}$ & $0,21^{* *}$ & $0,17^{* *}$ \\
\hline
\end{tabular}

${ }^{*} \mathrm{p}<0,05,{ }^{* *} \mathrm{p}<0,01$

Iz Tablice 2 vidi se da su korelacije među mjerama svih komponenti i potkomponenti generativnosti pozitivne i značajne, izuzev što mjere važnosti ciljeva djelovanja i povjerenja $\mathrm{u}$ ljude nisu bile povezane. Utvrđene značajne i, uglavnom, umjereno visoke povezanosti mjera raznih komponenti gene- 
rativnosti poklapaju se s pretpostavkama McAdamsa i de St. Aubina (1992.) da bi različite komponente generativnosti trebale biti umjereno povezane jer konvergiraju prema općem konstruktu generativnosti.

\section{Spolne i dobne razlike u komponentama generativnosti}

Kako bi se odgovorilo na drugi problem ovoga istraživanja, tj. kako bi se ispitalo postoje li spolne i dobne razlike $\mathrm{u}$ izraženosti pojedinih komponenti generativnosti, proveden je niz dvosmjernih analiza varijance sa spolom (muškarci - žene) i dobi (mlađi - srednji - stariji odrasli) kao nezavisnim varijablama i njihovim interakcijskim efektom te pojedinom komponentom generativnosti kao zavisnom varijablom. Rezultati ovih analiza prikazani su u Tablici 3. Uzorak je uključivao 150 muškaraca i 150 žena. Za potrebe ispitivanja dobnih razlika, uzorak kontinuiran s obzirom na dob podijeljen je $\mathrm{u}$ tri dobne podskupine: mlađu, srednju i stariju. Skupinu mlađe odrasle dobi činili su sudionici od 25 do 40 godina $(\mathrm{N}=90$, $\mathrm{M}=32,61, \mathrm{SD}=4,62)$, skupinu srednje odrasle dobi oni od 41 do 60 godina $(\mathrm{N}=120, \mathrm{M}=50,70, \mathrm{SD}=5,58)$, a skupinu starije odrasle dobi činili su sudionici stariji od 60 godina $(\mathrm{N}=90$, $\mathrm{M}=67,95, \mathrm{SD}=4,43)$. U skupini srednje odrasle dobi bilo je više ispitanika nego $\mathrm{u}$ druge dvije dobne podskupine, zato što razdoblje srednje odrasle dobi pokriva veći raspon godina $u$ odnosu na druga dva razdoblja odrasle dobi.

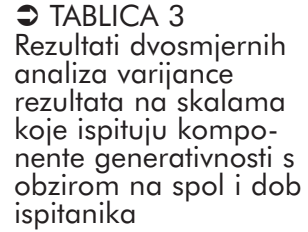

ispitanika

\begin{tabular}{llrrr}
\hline Zavisna varijabla & Efekt & $\mathrm{F}$ & $\mathrm{df}$ & $\mathrm{p}(\mathrm{F})$ \\
\hline Djelovanje & Spol & 1,120 & $1 / 294$ & 0,290 \\
& Dob & 9,582 & $2 / 294$ & 0,000 \\
& Spol $\times$ Dob & 0,874 & $2 / 294$ & 0,418 \\
Zajedništvo & Spol & 25,594 & $1 / 294$ & 0,000 \\
& Dob & 1,154 & $2 / 294$ & 0,317 \\
Generativna briga & Spol $\times$ Dob & 1,972 & $2 / 294$ & 0,141 \\
& Spol & 0,103 & $1 / 294$ & 0,751 \\
Povjerenje u ljude & Dob & 0,112 & $2 / 294$ & 0,898 \\
& Spol $\times$ Dob & 0,221 & $2 / 294$ & 0,801 \\
& Spol & 1,297 & $1 / 294$ & 0,255 \\
Nada u budućnost & Dob & 11,449 & $2 / 294$ & 0,000 \\
& Spol $\times$ Dob & 2,524 & $2 / 294$ & 0,081 \\
& Spol & 2,264 & $1 / 294$ & 0,134 \\
Generativna predanost & Dob & 0,322 & $2 / 294$ & 0,723 \\
& Spol $\times$ Dob & 2,801 & $2 / 294$ & 0,062 \\
& Spol & 0,700 & $1 / 294$ & 0,404 \\
Generativno djelovanje & Dob & 1,162 & $2 / 294$ & 0,314 \\
& Spol×Dob & 0,894 & $2 / 294$ & 0,412 \\
& Spol & 4,703 & $1 / 294$ & 0,030 \\
& Dob & 1,654 & $2 / 294$ & 0,193 \\
& Spol $\times$ Dob & 1,968 & $2 / 294$ & 0,141 \\
\hline
\end{tabular}


DRUŠ. ISTRAŽ. ZAGREB GOD. 20 (2011), BR. 3 (113),

STR. 671-692

TUCAK JUNAKOVIĆ, I.: NEKI ASPEKTI BRIGE...

$\rightarrow$ SLIKA 2 Prosječne vrijednosti rezultata na Skali važnosti ciljeva djelovanja u tri dobne podskupine
Ukratko, dvosmjernim analizama varijance utvrđen je značajan glavni efekt dobi na rezultate na skali djelovanja (kao mjeri jednog aspekta generativne želje) i na rezultate na skali povjerenja u ljude (kao mjeri jednog aspekta komponente vjere u vrstu). Značajan glavni efekt spola utvrđen je za rezultate na skali ciljeva zajedništva i za rezultate na Skali generativnoga djelovanja. Značajan interakcijski efekt spola i dobi nije utvrđen.

Kao što se vidi iz Tablice 3, rezultati dvosmjerne analize varijance pokazali su značajne dobne razlike $\mathrm{u}$ djelovanju. Pokazalo se da rezultati na skali djelovanja imaju tendenciju opadanja s dobi, što je u skladu s utvrđenom negativnom povezanosti dobi i važnosti ciljeva djelovanja (vidi Tablicu 2). Post-hoc analize, uz upotrebu Scheffé-testa, pokazale su postojanje značajnih razlika među mlađim odraslima $\mathrm{i}$ ispitanicima srednje odrasle dobi $(p=0,027)$, kao i među mlađim i starijim odraslima $(p=0,000)$. U oba slučaja mlađi odrasli postigli su značajno više rezultate na skali djelovanja $(\mathrm{M}=3,81)$ u odnosu na osobe srednje $(\mathrm{M}=3,56)$ i starije $(\mathrm{M}=3,39)$ odrasle dobi, što se vidi i iz Slike 2.

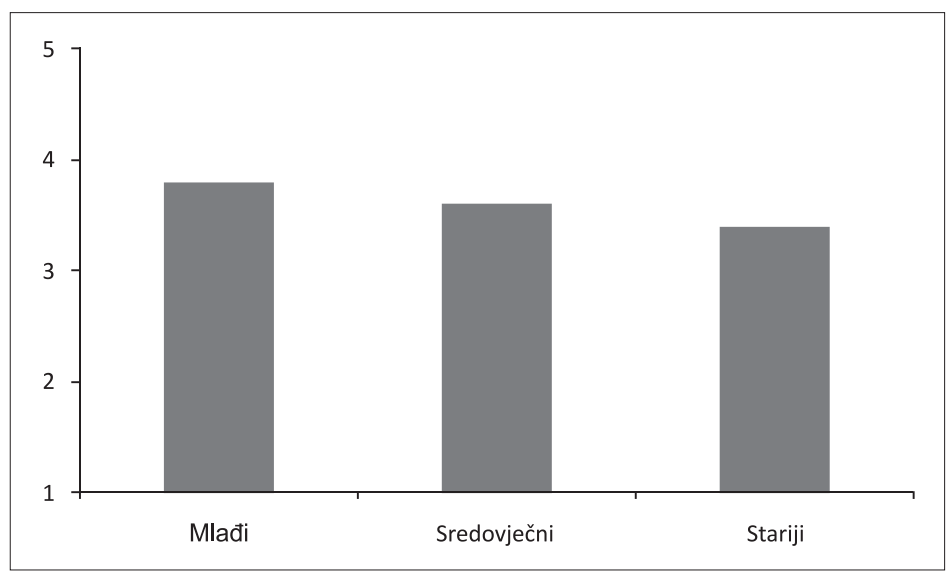

Nadalje, rezultati dvosmjerne analize varijance pokazali su značajan glavni efekt spola na rezultate na skali zajedništva. Pokazalo se da žene $(M=4,47)$ postižu značajno više rezultate na ovoj skali u odnosu na muškarce $(M=4,17)$, što se vidi i iz Slike 3.

Rezultati dvosmjernih analiza varijance nisu pokazali značajne glavne efekte spola, dobi, ni značajan utjecaj njihove interakcije na rezultate koje su ispitanici postigli na mjerama komponenti generativne brige, predanosti generativnim ciljevima i generativnoga djelovanja, kao sržnih komponenti McAdamsova i de St. Aubinova modela. Jedina iznimka bila je utvrđena značajna spolna razlika u komponenti generativnoga djelovanja, na kojoj su žene $(\mathrm{M}=2,91)$ u prosjeku postigle značajno više rezultate u odnosu na muškarce $(\mathrm{M}=2,76)$ (Slika 3). 
$\rightarrow$ SLIKA 3

Prosječne vrijednosti rezultata na Skali važnosti cilieva zajedništva i na Skali generativnoga djelovanja u muškaraca i žena

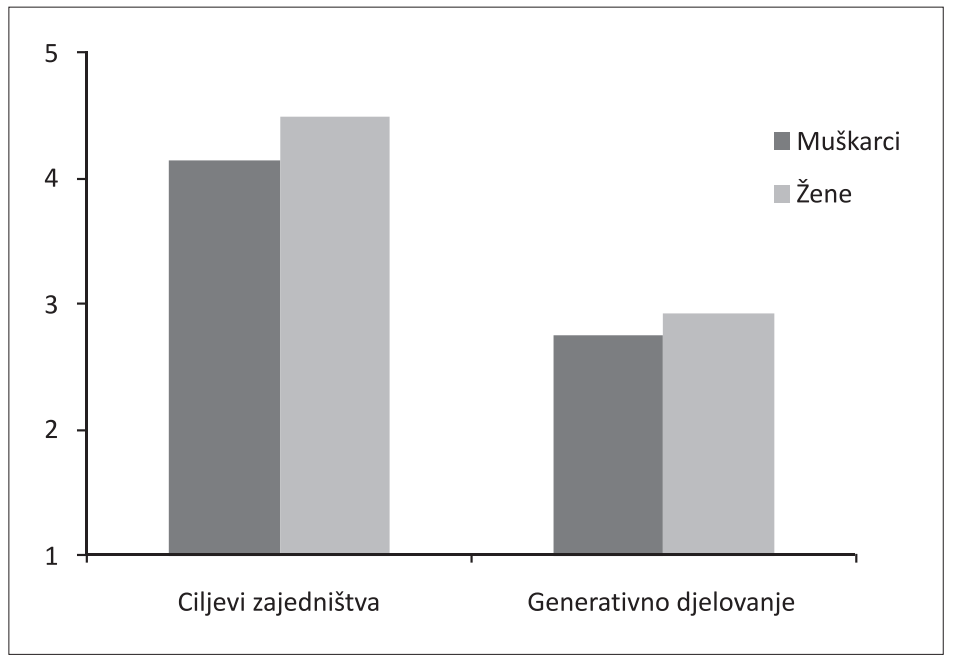

Ispitivanje spolnih i dobnih razlika u rezultatima na skalama povjerenja u ljude i nade u budućnost, koje su uzete kao operacionalizacija dviju potkomponenti konstrukta vjere $u$ vrstu, pokazalo je samo značajan glavni efekt dobi na rezultate na Skali povjerenja. Scheffé-test pokazao je postojanje značajne razlike $(\mathrm{p}=0,002) \mathrm{u}$ rezultatima na ovoj skali među skupinama mlađe $(M=0,25)$ i srednje $(M=0,73)$ odrasle dobi te značajne razlike $(p=0,000)$ među skupinama mlađe i starije $(\mathrm{M}=0,91)$ odrasle dobi. $\mathrm{U}$ obje su usporedbe mlađi odrasli postigli značajno niže rezultate na ovoj skali u odnosu na dvije starije dobne skupine. Općenito je vidljiva tendencija porasta rezultata na Skali povjerenja s dobi, što se poklapa s rezultatima korelacijske analize, koja je pokazala postojanje značajne pozitivne povezanosti rezultata na ovoj skali s dobi (vidi Tablicu 2). O rezultatima ispitivanja konstrukta povjerenja $u$ ljude i dobnih razlika u ovom konstruktu na istom uzorku odraslih osoba već smo ranije pisali (Tucak Junaković i Ćubela Adorić, 2009.).

U rezultatima na Skali nade u budućnost nisu utvrđene značajne spolne ni dobne razlike, ni značajan utjecaj interakcije spola i dobi. Čini se da muškarci i žene, kao i razne dobne podskupine odraslih, izražavaju u prosjeku sličan stupanj optimizma prema budućnosti, nade u bolji život za buduće generacije, vjere u napredak čovječanstva i sl.

\section{RASPRAVA}

Generativnost se odnosi na sve što čovjek stvara, o čemu se brine i što na koncu ostavlja za sobom, bilo da su to vlastiti potomci, materijalni proizvodi ili ideje. Ova "ostavština" pojedinca pridonosi dobrobiti mlađih generacija i društva u kojem će one živjeti. Iako je Eriksonov koncept generativnosti 
DRUŠ. ISTRAŽ. ZAGREB GOD. 20 (2011), BR. $3(113)$

STR. 671-692

TUCAK JUNAKOVIĆ, I.: NEKI ASPEKTI BRIGE.. doživio brojne elaboracije (Bradley i Marcia, 1998.; Peterson i Stewart, 1996.; Stewart i Vandewater, 1998. itd.), najsustavniji prikaz ovoga konstrukta predstavlja McAdamsov i de St. Aubinov model (McAdams i de St. Aubin, 1992.). Ovaj model opisuje generativnost kao složeni konstrukt koji uključuje sedam komponenti okupljenih oko zajedničkoga cilja promicanja dobrobiti i razvoja budućih generacija. U dosadašnjim istraživanjima i na stranim i na našim uzorcima nije istodobno zahvaćan veći broj komponenti ovoga modela (Hart i sur., 2001.; McAdams i de St. Aubin, 1992.; McAdams i sur., 1993.; Penezić i sur., 2008; Peterson i Stewart, 1996.). Uglavnom su ispitivane komponente generativne brige, predanosti i generativnoga djelovanja. Komponenta vjere u vrstu gotovo uopće nije ispitivana. Stoga je cilj ovoga istraživanja bio zahvatiti veći broj komponenti McAdamsova i de St. Aubinova modela, tj. sve osim kulturnih zahtjeva i generativne priče. Točnije, cilj je bio ispitati odnose među zahvaćenim komponentama generativnosti te spolne i dobne razlike $\mathrm{u}$ tim komponentama.

Treba naglasiti da je, za razliku od ranijih istraživanja, svih pet ispitanih komponenti generativnosti (od kojih su želja za generativnosti i vjera u vrstu uključivale dvije potkomponente) operacionalizirano skalama samoprocjene. Njihova je primjena jednostavnija $u$ odnosu na neke druge metode mjerenja koje su se ranije rabile za ispitivanje nekih komponenti, primjerice, projektivne mjere kao način ispitivanja želje za generativnosti (McAdams i sur., 1986.; Peterson i Stewart, 1993., 1996.). Rezultati na mjerama svih ispitanih komponenti i potkomponenti generativnosti bili su značajno i pozitivno povezani. Jedina iznimka odnosila se na nepovezanost važnosti ciljeva djelovanja i povjerenja u ljude. Dobivene značajne, pozitivne i umjereno visoke korelacije među gotovo svim ispitanim komponentama generativnosti u skladu su s postavkama McAdamsova i de St. Aubinova modela i rezultatima nekih ranijih istraživanja povezanosti pojedinih komponenti (Hart i sur., 2001.; McAdams i de St. Aubin, 1992.; McAdams i sur., 1993.; Penezić i sur., 2008.; Tucak, 2006.). Naime, prema ovom modelu, te bi korelacije trebale biti značajne i umjereno visoke, jer su ove komponente, premda međusobno različite, dijelovi istoga nadređenog konstrukta.

Rezultati ovoga istraživanja nisu potvrdili pretpostavke utemeljene na razvojnim očekivanjima i rezultatima nekih ranijih istraživanja (Keyes i Ryff, 1998.; McAdams i sur., 1993.; Peterson i Klohnen, 1995., i dr.) da bi generativnost, općenito, trebala biti najrazvijenija u srednjoj odrasloj dobi. Erikson je generativnost smatrao razvojnim zadatkom srednje odrasle dobi. Smatrao je da je srednja dob razvojni stadij u kojem se radijus brige širi s bliskih osoba i vlastite obitelji na mlađe generacije i društvo u cjelini. Polazeći od Eriksona, i svi drugi 
DRUŠ. ISTRAŽ. ZAGREB GOD. 20 (2011) BR. $3(113)$

STR. 671-692

TUCAK JUNAKOVIĆ, I.: NEKI ASPEKTI BRIGE... autori koji su proučavali generativnost slažu se da je ona karakteristika odrasle dobi, primarno srednje odrasle dobi. To je razdoblje u kojem i društvo očekuje od odraslih osoba da preuzmu odgovornost za dobrobit mlađih generacija ili da pridonesu očuvanju postojećih vrijednosti i tradicija njihovim prenošenjem sljedećoj generaciji. Suprotno ovim tvrdnjama, ovo istraživanje pokazalo je da dobne razlike u većini ispitanih komponenti generativnosti nisu bile značajne. Točnije, pokazalo se da se osobe mlađe ( 25 - 40 godina), srednje ( 41 60 godina) i starije (61 - 75 godina) odrasle dobi ne razlikuju značajno u rezultatima postignutima na mjerama važnosti ciljeva zajedništva, generativne brige, nade u budućnost, generativne predanosti i generativnoga djelovanja. Drugim riječima, dobiveni rezultati sugeriraju da generativnost ne mora biti obilježje isključivo srednje odrasle dobi, nego da u sličnoj mjeri može biti izražena tijekom cijele odrasle dobi.

Značajne dobne razlike utvrđene su jedino u rezultatima na Skali povjerenja u ljude, kao mjeri jedne potkomponente vjere u vrstu. Pokazalo se da mlađi odrasli postižu značajno niže rezultate na Skali povjerenja u odnosu na skupine srednje i starije odrasle dobi. Moguće je da kumuliranje pozitivnih iskustava proizašlih iz socijalnih interakcija s dobi dovodi do porasta povjerenja u ljudsku prirodu. Ovi nalazi mogu se dovesti i u vezu s pretpostavkom teorije socioemocionalne selektivnosti o velikoj važnosti što je ostvarivanje emocionalno bliskih odnosa s manjim brojem prisnih osoba ima za starije ljude (Carstensen, 1995.). Vjerojatno ugodne socijalne interakcije sa, kako osoba stari, sve užim krugom emocionalno bliskih osoba s dobi dovode do porasta povjerenja u ljudsku prirodu. Rezultati ranijih istraživanjima na stranim (Wrightsman, 1992.) i na našim uzorcima (Ćubela Adorić i Tucak, 2006.) također sugeriraju da stariji (odrasli) imaju općenito povoljnija vjerovanja o ljudskoj prirodi od mlađih skupina (studenata).

Jedina iznimka u odnosu na opće očekivanje da bi različite komponente generativnosti trebale biti najizraženije $\mathrm{u}$ srednjoj odrasloj dobi bila je pretpostavka da bi djelovanje, komponenta generativne želje, moglo biti najizraženije u mlađoj odrasloj dobi, što se slaže s nekim ranijim nalazima (Stewart i Vandewater, 1998.). Ova je pretpostavka istraživanjem potvrđena, jer se pokazalo da su osobama mlađe odrasle dobi ciljevi djelovanja bili značajno važniji nego osobama srednje i starije odrasle dobi. Ovaj je rezultat u skladu s razvojnim očekivanjima veće važnosti ciljeva djelovanja u mlađoj dobi u odnosu na kasnije periode odrasle dobi. Naime, neki autori (Levinson i sur., 1978.; Nurmi, 1997.) navode kako su glavni razvojni zadaci mlađe odrasle dobi vezani uz napuštanje roditeljskoga doma i ostvarivanje autonomije te uz započinjanje profesionalne karijere. Većina ovih razvojnih zadataka odražava se u 
DRUŠ. ISTRAŽ. ZAGREB GOD. 20 (2011), BR. 3 (113)

STR. 671-692

TUCAK JUNAKOVIĆ, I.: NEKI ASPEKTI BRIGE... apstraktnijim životnim ciljevima djelovanja, tj. moći i dostignuća. Stoga je mlađim odraslima, više nego starijim skupinama odraslih, važno ostvariti utjecaj na druge, dobiti priznanje od drugih, razvijati vlastite sposobnosti, obrazovati se i sl.

Dobiveni rezultat koji govori o većoj važnosti što je ciljevi djelovanja imaju za ispitane osobe mlađe odrasle dobi može se pokušati razumjeti i u kontekstu nekih sociodemografskih obilježja ove dobne skupine. Naime, u skupini mlađih odraslih bilo je više visokoobrazovanih nego u skupinama sredovječnih i starijih ispitanika. Valja pretpostaviti da su obrazovanije osobe usmjerenije prema razvijanju sposobnosti, unaprjeđivanju obrazovanja, postizanju visokoga socijalnog statusa, dobivanju javnoga priznanja i sl., tj. ciljevima usmjerenima dostignuću i moći. Viši stupanj obrazovanja možda se percipira kao olakšavajuća okolnost u postizanju ovih ciljeva. Uz to, $\mathrm{u}$ skupini mlađih odraslih bilo je više samaca te manje roditelja nego u dvije starije skupine, a sklapanje braka i roditeljstvo mogu se smatrati ciljevima koji prije ulaze u domenu ciljeva zajedništva.

U pogledu spolnih razlika, rezultati ovoga istraživanja nisu potvrdili očekivanje o razvijenijoj komponenti djelovanja u muškaraca, dok su potvrdili očekivanje da će komponenta zajedništva biti razvijenija u žena. Ovo drugo poklapa se s razlikama u procesu socijalizacije, u kojem je kod žena veći naglasak na usmjerenosti na druge, osjetljivosti za tuđe potrebe, pomaganju drugima i ostvarivanju bliskih odnosa.

Rezultati su također uglavnom potvrdili očekivanje (osim za komponentu generativnoga djelovanja) da spolne razlike u ostalim komponentama generativnosti ne bi trebale biti značajne, što je i u skladu s rezultatima nekih drugih istraživanja (Hart i sur., 2001.; McAdams i sur., 1993.; Tucak, 2005.). Točnije, pokazalo se da se muškarci i žene ne razlikuju značajno u rezultatima postignutima na mjerama važnosti ciljeva djelovanja, povjerenja $u$ ljude, nade $u$ budućnost, generativne brige i predanosti generativnim ciljevima. Generalno gledano, u "brizi za stvaranje i vođenje sljedeće generacije" (Erikson, 1984., 240) ne bi ni trebalo biti značajnih spolnih razlika, jer je ona duboko ukorijenjena u ljudskoj prirodi - i muškoj i ženskoj.

Suprotno ovome, jedino se pokazalo da žene izvješćuju o većoj frekvenciji generativnoga djelovanja, mjerenoga Skalom generativnoga djelovanja. Moguće je da je ovakva razlika dobivena zato što se veći dio čestica ove skale odnosi na prosocijalno orijentirane, pomagačke aktivnosti. Tradicionalna ženska rodna uloga, u odnosu na mušku, uključuje veću upućenost na takve aktivnosti. Slično ovome, Morfei i sur. (2004.) utvrdili su da žene, u odnosu na muškarce, izvode značajno više generativnih ponašanja koja su odraz zajedništva, tj. bri- 
DRUŠ. ISTRAŽ. ZAGREB GOD. 20 (2011), BR. $3(113)$

STR. 671-692

TUCAK JUNAKOVIĆ, I. NEKI ASPEKTI BRIGE...

\section{ZAKLJUČAK}

\section{LITERATURA}

ge za druge, $u$ različitim životnim domenama (posao, volonterski rad, aktivnosti u slobodno vrijeme). S druge strane, nisu utvrdili značajne spolne razlike u generativnim ponašanjima koja su odraz djelovanja, tj. želje da se ostavi vlastiti trag u svijetu. Međutim, da žene općenito više generativno djeluju pokazuju i rezultati nekih drugih istraživanja (Hart i sur., 2001.; Keyes i Ryff, 1998.; Shin An i Cooney, 2006.), pri čemu su u njima primijenjene drugačije mjere generativnoga djelovanja nego u ovom istraživanju.

Ovim je istraživanjem na dobno heterogenom uzorku odraslih zahvaćeno pet komponenti generativnosti iz McAdamsova i de St. Aubinova modela, tj. sve osim kulturnih zahtjeva za generativnosti i generativne priče. Ispitati svih sedam komponenti modela mogao bi biti cilj jednog od budućih istraživanja konstrukta generativnosti. Rezultati ovoga istraživanja impliciraju da je generativnost kao razvojno pitanje prisutna ne samo u srednjoj nego i u mlađoj i starijoj odrasloj dobi. Međutim, ovdje treba spomenuti da bi neka drugačija kronološka određenja razdoblja mlađe, srednje i starije odrasle dobi možda rezultirala drugačijim nalazima. Primjerice, da su u skupinu mlađe odrasle dobi uključene samo osobe mlađe od 30 godina, za koje se može pretpostaviti da su primarno zaokupljene zadatkom formiranja intimnih veza, a u skupinu starije odrasle dobi oni stariji od, primjerice, 75 godina, za koje se može pretpostaviti da su zaokupljeni zadaćom održanja vjerovanja u smislenost i vrijednost života te suočavanjem s blizinom smrti, možda bi se pokazalo da su ove dvije ovako kronološki definirane dobne skupine manje zaokupljene generativnošću nego skupina sredovječnih osoba. Ove bi se pretpostavke mogle provjeriti u budućim istraživanjima. Međutim, treba naglasiti da među istraživačima nema potpunoga konsenzusa oko kronoloških određenja pojedinih razdoblja odrasle dobi.

Nadalje, rezultati ovoga istraživanja pokazali su da se muškarci i žene ne razlikuju značajno u većini ispitanih komponenti generativnosti. Međutim, rezultati također upućuju na veću usmjerenost žena prema ciljevima zajedništva i prema njihovoj većoj sklonosti konkretnom generativnom djelovanju.

Ackerman, S., Zuroff, D. C. i Moskowitz, D. S. (2000.), Generativity in Midlife and Young Adults: Links to Agency, Communion, and Subjective Well-Being. International Journal of Aging and Human Development, 50 (1): 17-41.

Bradley, C. L. i Marcia, J. E. (1998.), Generativity - Stagnation: A Five-Category Model. Journal of Personality, 66 (1): 39-64. doi:10.1111/14676494.00002 
DRUŠ. ISTRAŽ. ZAGREB GOD. 20 (2011), BR. $3(113)$

STR. $671-692$

TUCAK JUNAKOVIĆ, I.: NEKI ASPEKTI BRIGE...
Carstensen, L. L. (1995.), Evidence for a Life-Span Theory of Socioemotional Selectivity. Current Directions in Psychological Science, 4 (5): 151-156. doi:10.1111/1467-8721.ep11512261

Ćubela Adorić, V. i Tucak, I. (2006.), Skala cinizma i povjerenja (CIP). U: V. Ćubela Adorić, A. Proroković, Z. Penezić i I. Tucak. (ur.), Zbirka psihologijskih skala i upitnika, 3 (str. 15-23), Zadar, Sveučilište u Zadru.

De St. Aubin, E. i McAdams, D. P. (1995.), The Relations of Generative Concern and Generative Action to Personality Traits, Satisfaction/ Happiness with Life and Ego Development. Journal of Adult Development, 2 (2): 99-112. doi:10.1007/BF02251258

Domino, G. i Hannah, M. T. (1989.), Measuring Effective Functioning in the Elderly: An Application of Erikson's Theory. Journal of Personality Assessment, 53 (2): 319-328. doi:10.1207/s15327752jpa5302_9

Erikson, E. (1984.), Childhood and Society, London, Triad Paladin.

Hart, H. M., McAdams, D. P., Hirsch, B. J. i Bauer, J. J. (2001.), Generativity and Social Involvement among African Americans and White Adults. Journal of Research in Personality, 35 (2): 208-230. doi:10.1006/ jrpe.2001.2318

Keyes, C. L. M. i Ryff, C. D. (1998.), Generativity in Adult Lives: Social Structural Contours and Quality of Life Consequences. U: D. P. McAdams i E. de St. Aubin (ur.), Generativity and Adult Development: How and Why We Care for the Next Generation (str. 227-263), Washington, D.C., APPA Press.

Lacković-Grgin, K., Penezić, Z. i Tucak, I. (2002.), Odnos generativnosti i drugih komponenti ličnosti Eriksonova modela u osoba mlađe, srednje i starije odrasle dobi. Suvremena psihologija, 5 (1): 9-30.

Levinson, D. J., Darrow, C., Klein, E., Levinson, M. i McKee, B. (1978.), The Seasons of a Man's Life, New York, Knopf.

McAdams, D. P. i de St. Aubin, E. (1992.), A Theory of Generativity and Its Assessment through Self-Report, Behavioral Acts and Narrative Themes in Autobiography. Journal of Personality and Social Psychology, 62 (6): 1003-1015. doi:10.1037//0022-3514.62.6.1003

McAdams, D. P., de St. Aubin, E. i Logan, R. L. (1993.), Generativity among Young, Midlife and Older Adults. Psychology and Aging, 8 (2): 221-230. doi:10.1037//0882-7974.8.2.221

McAdams, D. P., Hart, H. M. i Maruna, S. (1998.), The Anatomy of Generativity. U: D. P. McAdams i E. de St. Aubin (ur.), Generativity and Adult Development: How and Why We Care for the Next Generation (str. 7-43), Washington, D.C., APPA Press.

McAdams, D. P., Ruetzel, K. i Foley, J. M. (1986.), Complexity and Generativity at Midlife: Relations among Social Motives, Ego Development, and Adults' Plans for the Future. Journal of Personality and Social Psychology, 50 (4): 800-807. doi:10.1037//0022-3514.50.4.800

Morfei, M. Z., Hooker, K., Carpenter, J. Mix, C. i Blakeley, E. (2004.), Agentic and Communal Generative Behavior in Four Areas of Adult Life: Implications for Psychological Well-Being. Journal of Adult Development, 11 (1): 55-58. doi:10.1023/B:JADE.0000012528.25409.aa 
DRUŠ. ISTRAŽ. ZAGREB GOD. 20 (2011), BR. 3 (113)

STR. 671-692

TUCAK JUNAKOVIĆ, I. NEKI ASPEKTI BRIGE...
Nurmi, J. E. (1997.), Self-Definition and Mental Health During Adolescence and Young Adulthood. U: J. Schulenberg, J. L. Maggs i K. Hurrelmann (ur.), Health Risks and Developmental Transitions during Adolescence (str. 395-419), London, Cambridge University Press.

Penezić, Z., Lacković-Grgin, K., Tucak, I., Nekić, M., Žorga, S., Poljšak Škraban, O. i Vehover, U. (2008.), Predictors of Generative Action among Adults in Two Transitional Countries. Social Indicator Research, 87 (2): 237-248.

Peterson, B. E. i Duncan, L. E. (1999.), Generative Concern, Political Commitment, and Charitable Actions. Journal of Adult Development, 6 (2): 105-118. doi:10.1023/A:1021620824878

Peterson, B. E. i Klohnen, E. C. (1995.), Realization of Generativity in Two Samples of Women at Midlife. Psychology and Aging, 10 (1): 20-29. doi:10.1037//0882-7974.10.1.20

Peterson, B. E., Smirles, K. A. i Wentworth, P. A. (1997.), Generativity and Authoritarianism: Implications for Personality, Political Involvement, and Parenting. Journal of Personality and Social Psychology, 72 (5): 1202-1216. doi:10.1037//0022-3514.72.5.1202

Peterson, B. E. i Stewart, A. J. (1993.), Generativity and Social Motives in Young Adults. Journal of Personality and Social Psychology, 65 (1): 186-198. doi:10.1037//0022-3514.65.1.186

Peterson, B. E. i Stewart, A. J. (1996.), Antecedents and Contexts of Generativity Motivation at Midlife. Psychology and Aging, 11 (1): 21-33. doi:10.1037//0882-7974.11.1.21

Pöhlmann, K. i Brunstein, J. C. (1997.), GOALS: Ein Fragebogen zur Messung von Lebenszielen. Diagnostica, 43 (1): 63-79.

Shin An, J. i Cooney, T. M. (2006.), Psychological Well-Being in Mid to Late Life: The Role of Generativity Development and Parent-Child Relationships Across the Lifespan. International Journal of Behavioral Development, 30 (5): 410-421.

Stewart, A. J. i Vandewater, E. A. (1998.), The Course of Generativity. U: D. P. McAdams i E. de St. Aubin (ur.), Generativity and Adult Development: How and Why We Care for the Next Generation (str. 75-100), Washington, D.C., APPA Press.

Tucak, I. (2005.), Generativna briga u tri perioda odrasle dobi: Relacija s nekim sociodemografskim varijablama, životnim zadovoljstvom i percepcijom osobne (ne)kompetentnosti. Suvremena psihologija, 8 (2): 179-195.

Tucak, I. (2006.), Skala generativnog djelovanja. U: V. Ćubela Adorić, A. Proroković, Z. Penezić i I. Tucak (ur.), Zbirka psihologijskih skala $i$ upitnika, 3 (str. 25-32), Zadar, Sveučilište u Zadru.

Tucak Junaković, I. (2008.), Skraćena verzija upitnika važnosti životnih ciljeva. U: Z. Penezić, V. Ćubela Adorić, A. Proroković i I. Tucak Junaković (ur.), Zbirka psihologijskih skala i upitnika, 4 (str. 73-84), Zadar, Sveučilište u Zadru.

Tucak Junaković, I. (2009.), Provjera osnovnih postavki McAdamsova i de St. Aubinova modela generativnosti u odraslih različite dobi, Neobjavljena doktorska disertacija, Zagreb, Filozofski fakultet. 
DRUŠ. ISTRAŽ. ZAGREB GOD. 20 (2011), BR. 3 (113)

STR. $671-692$

TUCAK JUNAKOVIĆ, I.: NEKI ASPEKTI BRIGE...
Tucak Junaković, I. i Ćubela Adorić, V. (2009.), Odnos bazičnih vjerovanja o ljudskoj prirodi s usamljenošću, preferiranom samoćom i zadovoljstvom socijalnim odnosima u odrasloj dobi. Psihologijske teme, 18 (1): 159-182

Van de Water, D. A. i McAdams, D. P. (1989.), Generativity and Erikson's "Belief in the Species". Journal of Research in Personality, 23 (4): 435-449.

Wrightsman, L. S. (1992.), Assumptions About Human Nature, Newbury Park, Sage.

\section{Some Aspects of Adults' Concern for the Younger Generations: Sex and Age Differences}

\author{
Ivana TUCAK JUNAKOVIĆ \\ University of Zadar, Zadar
}

Erikson's concept of generativity refers to the concern for younger generations and for one's lasting contributions to society, which is the main issue of middle adulthood. After Erikson, the construct of generativity was elaborated by many authors, and its widest elaboration is presented in McAdams and de St. Aubin's model of generativity (1992). In previous testing of the model, the relations among a few of its components were tested. Therefore, the study was conducted with the aim to test the relations among five, out of seven, components of the model (generative desire, concern, commitment, belief in the species, and generative action), and to explore sex and age differences in those components. A sample of 300 adults 25 to 75 years old participated in the study. Components of generativity were measured by the previously developed scales, their adapted and culturally adjusted versions, or by the newly constructed scales. In line with the assumptions, the analyses showed that almost all of the generativity components correlated significantly and positively. The results also suggest that generativity is a developmental issue not only of the middle, but of the entire period of adulthood. Furthermore, sex differences in the majority of the components of generativity were not significant. Only communion orientation (as an aspect of generative desire), and generative action were more pronounced in women. The study results were interpreted in line with the theoretical approaches to generativity, primarily with those proposed by Erikson and McAdams and de St. Aubin, as well as in the context of theories of development in adulthood.

Keywords: generativity, McAdams and de St. Aubin's model, adulthood 
DRUŠ. ISTRAŽ. ZAGREB GOD. 20 (2011), BR. $3(113)$

STR. 671-692

TUCAK JUNAKOVIĆ, I. NEKI ASPEKTI BRIGE...

\section{Bestimmte Aspekte der Fürsorge von Erwachsenen für jüngere Generationen: Geschlechts- und altersbedingte Unterschiede}

\author{
Ivana TUCAK JUNAKOVIĆ \\ Universität Zadar, Zadar
}

Eriksons Begriff der Generativität betrifft Menschen der jüngeren Generation und meint deren erzieherischen Beitrag zum Wohle der Gesellschaft. Das Konstrukt der Generativität hat nach Erikson zahlreiche Erweiterungen erfahren, deren bedeutendste das Generativitätsmodell nach McAdams und De St. Aubin ist (1992). Bisherige Untersuchungen des Modells beschäftigten sich mit den Wechselbeziehungen zwischen einzelnen Komponenten. Mit der vorliegenden Untersuchung sollten die Wechselbeziehungen zwischen fünf von insgesamt sieben Modellkomponenten (Wunsch nach generativem Handeln, Fürsorge, Hingabe, Glaube an die Wirksamkeit des eigenen generativen Engagements sowie an die konkrete Tätigkeit) eingehender betrachtet werden. Des Weiteren wollte man herausfinden, welche geschlechts- und altersbedingten Unterschiede zwischen diesen Komponenten bestehen. An der Untersuchung nahmen 300 Personen zwischen 25 und 75 Jahren teil. Die Generativitätskomponenten wurden anhand bestehender Messskalen untersucht; zum Einsatz kamen ebenso kultural adaptierte Versionen oder ganz neu konstruierte Skalen.

Erwartungsgemäß erwies sich, dass nahezu alle untersuchten Generativitätskomponenten in einem wesentlichen und positiven Zusammenhang zueinander stehen. Die Ergebnisse suggerieren außerdem, dass das Phänomen der Generativität nicht nur ein Merkmal von Personen mittleren Alters ist, sondern durchgehend das gesamte Erwachsenenalter begleitet. Bei der Mehrzahl der Generativitätskomponenten konnten keine wesentlichen geschlechtsbedingten Unterschiede nachgewiesen werden. Einzig bei Fraven waren die Orientierung am Gemeinwesen (als den Wunsch nach Generativität auslösendes Moment) sowie generatives Handeln stärker ausgeprägt. Die Untersuchungsergebnisse wurden in Anlehnung an die Generativitätsmodelle von Erikson, McAdams und De St. Aubin sowie vor dem Hintergrund der Entwicklungspsychologie des Erwachsenenalters interpretiert.

Schlüsselbegriffe: Generativität, Modell nach McAdams und De St. Aubin, Erwachsenenalter 